$1-1-1979$

\title{
The feasibility of establishing low volume beef slaughtering - processing plants in West Virginia
}

Ronnie L. Durst

John P. Kuehn

Follow this and additional works at: https://researchrepository.wvu.edu/ wv_agricultural_and_forestry_experiment_station_bulletins

\section{Digital Commons Citation}

Durst, Ronnie L. and Kuehn, John P., "The feasibility of establishing low volume beef slaughtering - processing plants in West Virginia" (1979). West Virginia Agricultural and Forestry Experiment Station Bulletins. 666.

https://researchrepository.wvu.edu/wv_agricultural_and_forestry_experiment_station_bulletins/564 @ WVU. It has been accepted for inclusion in West Virginia Agricultural and Forestry Experiment Station Bulletins by an authorized administrator of The Research Repository @WVU. For more information, please contact ian.harmon@mail.wvu.edu. 


\section{The Feasibility of}

Establishing Low Velume Beef Slaughtering- Processing Plants in West Virginia

AG. ENGR. LIBRARY
WEST VIRGINIA UNIVERSITY

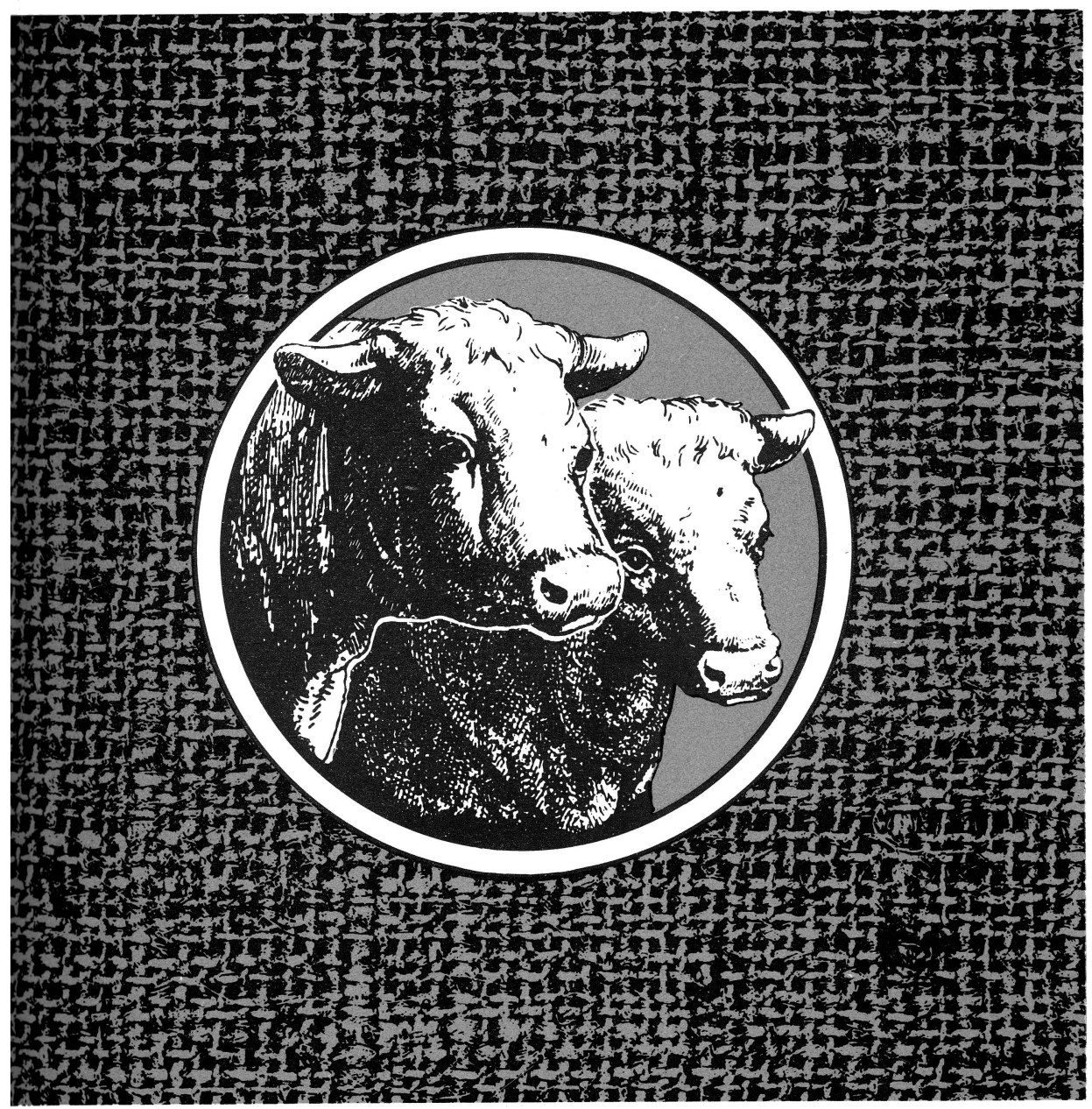

West Virginia University

Agricultural and Forestry Experiment Station

$\$ 127$

, El

no. 666 
Blank Page in Original Bulletin 


\section{Contents}

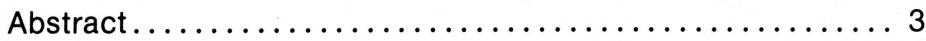

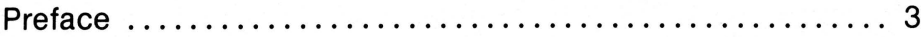

Summary and Conclusions ................... 4

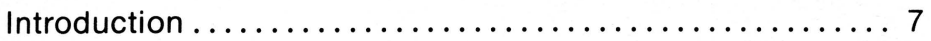

Objectives $\ldots \ldots \ldots \ldots \ldots \ldots \ldots \ldots \ldots \ldots \ldots \ldots \ldots \ldots$

Procedure $\ldots \ldots \ldots \ldots \ldots \ldots \ldots \ldots \ldots \ldots \ldots \ldots$

Cost Analysis $\ldots \ldots \ldots \ldots \ldots \ldots \ldots \ldots \ldots \ldots \ldots \ldots \ldots$

Annual Fixed Costs .......................... 10

Annual Operating Costs $\ldots \ldots \ldots \ldots \ldots \ldots \ldots \ldots \ldots \ldots$

Revenue and Feasibility Analysis ................ 14

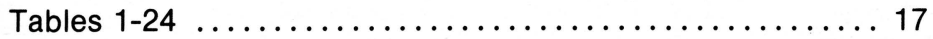

Bibliography and Literature Cited $\ldots \ldots \ldots \ldots \ldots \ldots \ldots$

Appendixes $\ldots \ldots \ldots \ldots \ldots \ldots \ldots \ldots \ldots \ldots \ldots \ldots \ldots \ldots . \ldots 4$ 


\title{
The Authors
}

At the time of this study, Ronnie L. Durst was a Graduate Research Assistant in the Division of Resource Management; John P. Kuehn is Associate Agricultural Economist.

\author{
West Virginia University \\ Agricultural and Forestry Experiment Station \\ College of Agriculture and Forestry \\ Dale W. Zinn, Director \\ Morgantown
}




\begin{abstract}
The overall objective of this study was to determine the feasibility of establishing and operating low volume beef slaughtering and processing plants in West Virginia. Benchmark data for ideal, efficient operating conditions were synthetically generated to provide operating guidelines for both prospective and existing plants.

Three plants were designed: Plant A, 1,512 head per year (6 head per day); Plant B, 5,040 head per year (20 head per day); Plant C, 6,300 head per year ( 25 head per day). The total initial investments were land, $\$ 95,418$; buildings, $\$ 237,451$; and equipment, $\$ 257,587$.

The optimum sized plant to build depended on expected annual volume. Plant $C$ provided the lowest cost per head slaughtered and processed. However, if Plant $C$ operated below 90 per cent of capacity, Plant B was found to be more efficient. Plant $A$ was marginal since a favorable product price situation was necessary for profitable operation.
\end{abstract}

\title{
Preface
}

The study results presented in this bulletin were based on an economic engineering analysis. The objective of such an analysis is to provide benchmark data which reflect ideal operating conditions. The criteria used for formulating the cost and return estimates considered legislative restrictions and conventional practices followed by major firms in the livestock industry.

Cost and return data so generated might not directly simulate actual operating conditions in the state. However, the object was to determine general relationships between various annual volumes and their associated costs and returns. These general relationships were designed to provide decision making criteria for the establishment of new firms. The study data could then be used as a benchmark mechanism. Individual situations could be compared to those of the study data for purposes of determining areas for improvements on the benchmark results. Examples of such improvements include locating on undeveloped industrial land, using well water rather than city water, using non-union labor, used equipment and buildings, etc.

Given these reservations the analysis should be useful for existing plants in the state as well as for organizations or individuals planning to establish new plants. 


\section{Summary and Conclusions}

A number of factors have caused structural shifts in the meat packing industry. Packing plants have been moving closer to the sources of slaughter animals. Basically, it is less expensive to transport processed meat than live animals. This trend, however, is complicated when supplies of slaughter animals are not concentrated and population centers are scattered.

Meat slaughtering and processing plants achieve great cost reductions as size and volume increase. However, in areas such as West Virginia, there are no significant concentrations of consumers. Possibly, the cost savings of large firms located close to live animal supplies could be offset by smaller, more centrally located firms which do not incur the large transportation costs required to ship processed meat to scattered isolated demand centers.

Therefore, the overall objective of this study was to evaluate the feasibility of establishing and operating small slaughtering-processing plants in West Virginia. Specifically; the objectives were: (1) to estimate the initial investment for various sized model beef slaughtering-processing plants; (2) to estimate annual operating costs; (3) to determine the effects of differing levels of capacity utilization on operating efficiency; and (4) to estimate expected net revenues for model plants operating under different sets of demand-supply conditions.

The procedure used to accomplish these objectives was synthetic cost analysis. Three efficient model plants were designed for West Virginia: (1) Plant $A, 1,512$ head per year $(6$ head per day slaughtered and processed); (2) Plant B, 5,040 head per year (20 head per day); (3) Plant C, 6,300 head per year (25 head per day). These model plants were then ana- 
lyzed based on different levels of capacity utilization and different final product prices.

The total initial investment in land, buildings, and equipment was $\$ 95,418$ for Plant A, $\$ 237,451$ for Plant B, and $\$ 257,587$ for Plant C, based on 1976 prices.

Study results indicated average costs decreased for each plant as the level of utilization and capacity increased from 70 to 100 percent. Operating at full capacity, Plant A costs averaged $\$ 81.47$ per head, or 15.5 cents per pound (based on an assumed average dressed weight of 525 pounds). Plant B costs averaged $\$ 56.15$ per head, or 10.7 cents per pound, and Plant C incurred costs of $\$ 55.35$ per head, or 10.5 cents per pound.

Expected revenues of the model plants were analyzed based on three price levels. The low price level assumed a base slaughtering fee of $\$ 5.00$ and a processing fee of 10 cents per pound. The medium price level assumed a base fee of $\$ 10.00$ and a processing charge of 12 cents per pound; the high price level assumed a $\$ 15.00$ slaughtering charge and a processing fee of 14 cents per pound. Annual net revenue, with the exception of Plant A, was positive in all cases. And, as expected, net revenue increased as plant size increased and also as levels of capacity utilization increased.

The optimum sized plant depends on the expected volume. Plant $C$ provides the lowest cost per head if it operates above 90 percent of capacity; below 90 percent Plant B is more efficient.

If the costs in this study are compared with the lower costs incurred by the large midwestern and southwestern firms, and the greater transportation costs from those areas are considered, small plants constructed in West Virginia might prove more efficient. 
Blank Page in Original Bulletin 


\title{
The Feasibility of Establishing Low Volume Beef Slaughtering- Processing Plants in West Virginia
}

\author{
RONNIE L. DURST AND JOHN P. KUEHN
}

The meat packing industry in the United States has undergone significant changes since the early 1950s. These changes include a shift from large, multispecies, slaughtering-processing plants located near terminal markets to plants specializing in the slaughter of one or two species, located near the production areas $(6$, p. 5). One of the major factors influencing these shifts has been the cost of transportation. Processed meat may be shipped less expensively than live animals. When there is a large concentration of animals ready for slaughter, such as in the Midwest or Southwest, a slaughter plant can be relatively large in order to take advantage of economies of size. In the case of West Virginia, however, there are no significant concentrations of live slaughter animals.

Economies of size are certainly important in the meat packing industry. However, the large variations in size of firms in the industry indicate that these economies may be offset by locational aspects of production and demand. "Spatially isolated demand centers often warrant a small firm whose costs of operation are less than those of larger more centrally located firms which must incur large transportation costs to ship their products to such isolated demand centers." (7, p. 1).

West Virginia has been a deficit processor of meat and meat products for some time. In 1973, only 18 percent of the meat consumed statewide was processed within the state. A large portion of that 18 percent was slaughtered outside the state and brought in for processing (13, p. 13).

Therefore, there is potential in the state for an increase in the slaughtering, processing, and sales of West Virginia produced meat. But since the nature of the state's livestock industry is to produce primarily feeder calves and since a relatively small number of slaughter animals are fed out, the small slaughter-processing plant appears to have more potential than the larger more "efficient" plants which require both a large number of animals and customers.

\section{OBJECTIVES}

The overall objective of the study was to evaluate the feasibility of establishing and operating small beef slaughtering-processing plants in West Virginia. Specifically, the objectives were:

1. To estimate the initial investment for various sized model beef slaughtering-processing plants

2. To establish annual operating costs for model slaughtering-processing plants

3. To determine the effects of differing levels of capacity utilization on operating efficiency 
4. To estimate expected net revenues for model plants operating under different sets of demand-supply conditions.

\section{PROCEDURE}

Cost data from 1976 were synthesized, through economic engineering techniques, for various sized model slaughtering plants. "Basically, the synthetic firm approach involves the development of budgets for hypothetical firms, using the best available estimates of the technical coefficients resource requirements and expected yields - and charging market prices or opportunity costs for all resources." (17, p. 29)

In this particular study, model slaughtering plants selected were con. sidered to be of optimum design and employ relatively efficient machinery and equipment for their individual size or output. Once these plants were selected, complete input-output and cost schedules were developed through allocation of costs to plant construction, equipment, land, labor, and other operating costs. These cost estimates were based on information obtained from contractors, equipment manufacturers, and various other sources.

There were two major sections of the analysis: a cost analysis section and a revenue and feasibility analysis section.

The cost analysis consisted of calculating costs per unit of output for each of the plants operating at full capacity. The effect of seasonal slaughter animal supply on operating costs was also calculated by the ratio-to-moving average method (9, pp. 440-447). Further examination of plant average costs was achieved by assuming plants would produce at 70 , 90 , and $120^{1}$ percent of capacity.

Once per unit costs were calculated for all levels of capacity utilization of the three plant sizes, short-run curves were constructed for each and a long. run cost curve was estimated from the three. In addition, an estimation was made as to the investment costs necessary for the establishment of each of the model plants.

Plant revenues were estimated at various levels of capacity. This was accomplished by estimating revenue per unit of output and then multiplying by the appropriate output level. The feasibility of establishing the model plants was estimated and analyzed through comparison of revenues and costs.

\section{Plant Characteristics}

The model plants used in this study were designed for custom kill or wholesale meat type operations. In a custom type operation, the customer provides a live animal and receives in return wrapped meat ready for the freezer. A wholesale type operation involves the purchase of live animals and then the sale of the processed meat either at the plant or to retail agencies in the area. For the purpose of this study, all costs and revenues were based on the custom type operation. The additional costs involved in buying and selling for the wholesale type operation were assumed to be offset by the additional revenue obtained by selling the processed meat.

'The 120 percent level of capacity utilization was achieved by assuming plants would operate six days per week instead of five. 
The plants used in this study were designed primarily to slaughter and process cattle. Hogs could also be slaughtered in these plants, but they were not included in this study.

For this particular analysis, the input-output relationships of three sizes of plant were synthesized. The maximum beef slaughter and processing capacity for the three plants were 6, 20, and 25 head per day.

Each plant was designed to meet federal restrictions and requirements on construction, layout, and equipment. This enables plant management to supplement custom type operations with commercial wholesale type operations during the periods when custom demand is low. Each plant consists of corral facilities, killing floor and processing room, employee welfare area, office space, chill and holding cooler, hide and offal room, and sufficient parking space for employees and visitors.

The plants when operating at full capacity were presumed to operate with a single labor shift of eight hours duration, five days a week, for 52 weeks a year with the exception of holidays. Thus, the total number of operating days per year is 252 .

\section{COST ANALYSIS}

For this particular analysis, costs will be viewed as either investment or operating. Investment costs are those not related to output and include those associated with land, buildings, and equipment. Operating costs are those related to output and consist of labor, utilities, and miscellaneous operating costs.

\section{Investment Requirements}

Building Requirements and Costs

The cost of constructing a custom slaughtering plant varies greatly depending upon the type of building being constructed, topography of the plant site, and the inspection requirements of federal, state, and local officials $(15$, p. 55). For this study it was assumed that plants would be constructed on level ground at suitable operational sites and that they would meet all requirements for federal inspection.

Equipment manufacturers, extension specialists, and industry sources were contacted regarding plant selection. A pre-engineered plant was selected for its efficient layout and design. To synthesize the building costs for the various sizes of plants, engineering and architectural drawings, along with cost estimates, were obtained from an equipment manufacturer. These building costs are illustrated in Table 1.

\section{Equipment Requirements and Costs}

Equipment costs considered in this study included all equipment necessary for the operation of a custom slaughtering plant: equipment for the slaughtering and processing areas, office areas, employee welfare areas, and all refrigeration equipment.

Industry sources provided specifications involving slaughtering, processing and refrigeration requirements, and costs. Detailed equipment listings for each of the model plants are presented in Appendix A.

Office and employee welfare equipment requirements were synthesized on the basis of the functions to be performed and the number and type of 
personnel employed. The costs were based on price listings of various retail agencies throughout West Virginia. Total equipment costs for each of the model plants are presented in Table 2.

\section{Land Requirements and Costs}

In determining the amount of land required for each plant, consideration was given to building space, employee and visitor parking, and future expansion and landscaping. The parking area requirements were calculated on the basis of 9 by 30 feet for each employee with equal space for visitors' parking. The miscellaneous land area was assumed to be ten percent of the combined building and parking area (14, p. 79).

Values of land suitable for plants ranged from $\$ 500.00$ to $\$ 10,000.00$ per acre. This large variation in land value occurs due to the accessibility to major highways and the particular section of the state considered.

Based on conversations with Chamber of Commerce officials, a cost of $\$ 5,000.00$ per acre, or approximately 11.5 cents per square foot, was used for estimating land costs. The land requirements and costs for each model plant are presented in Table 3.

\section{Total Investment Costs}

Total investment costs, an estimation of initial capital outlay required to establish slaughtering plants, include land, buildings, and equipment costs (Table 4).

\section{ANNUAL FIXED COSTS \\ Interest on Land, Buildings, and Equipment}

The firm must consider interest on funds invested is an annual investment cost. An interest rate of 9 percent was applied to the full value of the land. Building and equipment interest costs were based on a 9 percent rate applied to 50 percent of the original investment. This assumes the salvage value would be zero at the end of the depreciation period (14, p. 95). The interest costs for the model plants are presented in Table 5.

\section{Depreciation on Buildings and Equipment}

The estimated use life of buildings and equipment are 25 and 12.5 years, respectively. At the end of this period buildings are assumed to be completely depreciated, while equipment can be salvaged at 10 per cent of original costs $(8, p .11)$. Thus, buildings are depreciated at 4 percent per year, while equipment is depreciated at an 8 per cent annual rate applied to total cost minus salvage value. The annual depreciation costs for buildings and equipment are listed in Table 6.

\section{Property Taxes}

Personal property taxes were based on rates obtained from the Monongalia County Tax Assessor's office. Although tax rates vary from county to county within the state, these rates are similar to rates in other counties. The standard assessment rate, $\$ 2.68$ per $\$ 100.00$, is based on 50 percent of the market value of land, buildings, and equipment. The property taxes for each of the model plants are presented in Table 7. 


\section{Insurance}

Insurance coverages included in this study are fire, liability, and extended coverage. Although fire insurance rates vary greatly, a typical annual rate for similar buildings as those used in this study would be approximately $\$ .80$ per $\$ 100.00$ of investment in buildings and equipment. Liability is figured on a per square foot basis and was estimated at thirty cents per square foot of building space. Insurance costs, along with a complete listing of other annual investment costs, are presented in Table 7.

\section{ANNUAL OPERATING COSTS}

\section{Utilities}

\section{Electricity Requirements and Costs}

Electricity is used in each of the model plants for three purposes: lighting, operation of equipment motors, and operation of refrigeration units.

The lighting requirements for each of the model plants were synthesized using the Lumen method $(21$, p. 146). The Lumen method of calculation consists of six steps: "(1) determine the level of illumination, (2) select the lighting system and luminaires, (3) determine the coefficient of utilization, (4) estimate the maintenance factor, (5) calculate the number of lamps and (6) determine the location of the luminaires" (21, p. 146). For a more complete discussion of electricity requirements and the Lumen method, see Appendix B.

Electricity required for the operation of equipment motors was computed by assuming that each one-horsepower motor consumed .78 kilowatt per hour (6, p. 24). An estimated time of daily operation was established for each motor.

Electricity requirements for refrigeration purposes were calculated by using the following formula: $(6, p .16)$

\section{Where:}

$$
X=A B\left(t_{2}-t_{1}\right)
$$

$X=$ Amount of heat in B.T.U.'s that must be removed each hour to maintain the desired temperature.

$A=$ Number of square feet of wall space.

$B=$ Heat transfer coefficient of insulation material.

$\mathrm{t}_{2}=$ Temperature of outer wall.

$t_{1}=$ Temperature required inside room.

This formula estimates the amount of heat in B.T.U.'s that must be removed to maintain the temperature at the desired level. To estimate the B.T.U.'s of heat that must be removed to cool the carcasses, the following formula was used: $(6, p .17)$

Where:

$$
X=B S\left(t_{2}-t_{1}\right)
$$

$S=$ Specific heat of beef.

$B=$ Pounds of beef to be cooled.

$t_{2}=$ Unchilled beef temperature.

$t_{1}=$ Temperature required inside room.

For a more complete discussion of electricity requirements for refrigeration purposes, see Appendix B. 
Once the electrical requirements for each plant were determined, a monthly billing demand for each plant was estimated. This billing demand is based on kilowatt capacity necessary to serve the customer. Since this varies greatly, a rule of thumb used by electrical concerns -4 kilowatts for every 1000 kilowatt hours consumed (15, p. 83) - was used to estimate bill. ing demand.

The cost of the electricity for the model plants was based on General Service Rate Schedule C obtained from the Monongahela Power Company. Tables 8 and 9 summarize the electricity requirements and costs of the model plants at various levels of capacity utilization.

\section{Fuel Requirements and Costs}

Since fuel oil is available in most areas and is widely used for heating in rural areas, it was used for estimation of heating fuel costs. Fuel requirements were based on short cut procedures taken from the Handbook of Air Conditioning, Heating, and Ventilation. For a description of this pro. cedure, see Appendix C.

Fuel costs were based on prices obtained from several sources in the northern and central West Virginia areas. Fuel requirements and costs are presented in Table 10.

\section{Water Requirements and Costs}

Water is needed for animals to drink during the time spent in holding pens, floor and equipment clean-up, and for personal use of plant personnel. Water requirements were based on a linear function taken from Logan and King (15):

Where:

$$
Y=.362 X
$$

$Y=$ Yearly water consumption in 100 cubic feet.

$X=$ Yearly slaughter in number of head.

The water rates used were those charged by the Morgantown Water Commission. Schedule No. 1 was the appropriate schedule for small commercial users (see Appendix B). Two charges were involved: a basic charge for gallons used per month; and a sewage charge, which, according to Water Commission officials, is approximately 90 percent of the water costs. The annual water requirements and costs are shown in Table 11, and the annual costs of all utilities are summarized in Table 12.

\section{Labor Requirements and Costs}

Labor requirements at various levels of output were synthesized for each of the model plants. These requirements were based on estimates obtained from an equipment manufacturer and a sample of plant managers throughout West Virginia.

Plant personnel were divided into six departments: slaughtering, cutting and boning, order assembly, office personnel, sanitation and maintenance, and plant management. Total personnel requirements for each department within the model plants are presented in Table 13.

Wages for plant personnel were based on approximately 10 interviews with selected plant managers in West Virginia. Their identities were kept confidential, as they requested. Although these rates vary greatly, according to plant managers, qualified employees could be obtained at the wage 
rates used in this study. These rates were $\$ 4.50$ per hour for slaughtering and processing personnel and $\$ 3.00$ per hour for order assembly, sanitation and maintenance, and office personnel. Management salaries are generally related to plant size. Yearly salaries for plant management used in this study were $12,000,16,000$, and 18,000 dollars for the three sizes of model plants. These salaries were assumed to remain at these levels regardless of plant capacity utilization. Total wages for each of the model plants at their various levels of capacity utilization are presented in Appendix D.

Employee benefits are additional costs associated with plant personnel and wages. According to an American Meat Institute Survey of U.S. meat processing plants in 1975, employee benefits were approximately 26.2 percent of wages and salaries. These benefits include: social security, 6.3 percent; retirement, 5.1 percent; insurance and hospitalization, 6.2 percent; vacation and holidays, 7.0 percent; and other, 1.6 percent (1, p. 5). Employee benefit costs, along with in-plant labor costs for each of the model plants, are presented in Tables 14, 15, and 16.

\section{Miscellaneous Operating Costs}

Miscellaneous operating costs include repair and maintenance, killing supplies, office, processing and packaging, taxes and licenses, telephone, advertising, and laundry. In a similar study investigating economies of size in non-slaughtering meat processing plants, these costs were an average of 64 percent of the in-plant labor costs for plants processing less than 75,000 pounds weekly $(21$, p. 73$)$.

Although several other studies provide similar estimates, this study was used as a basis for estimating miscellaneous operating costs because it more closely approximates the sizes, technological configurations, and purposes of the model plants considered in this analysis. Miscellaneous operating costs for each of the model plants at their various levels of capacity utilization are illustrated in Table 17.

\section{Total Annual Costs}

Investment Costs

Total annual investment, or fixed costs, represented a small portion of total annual costs. These costs were $\$ 11,869, \$ 29,012$, and $\$ 32,056$ for the small, medium, and large plants, respectively (Table 18). At full capacity these costs represented $9.62,10.25$, and 9.19 percent of total annual costs for the model plants. Investment, or fixed costs, as a percent of total costs increased as output for each model plant decreased (Table 19).

\section{Operating Costs}

The largest portion of total annual costs consisted of the variable or operating costs. These costs included: payroll, miscellaneous operating, and utilities. Payroll costs comprised the largest portion of operating costs. Payroll costs ranged, depending on capacity utilization, from $\$ 55,215$ to $\$ 89,213$ for the small plant, from $\$ 121,705$ to $\$ 208,803$ for the medium plant, and from $\$ 150,944$ to $\$ 260,962$ for the large plant (Table 18).

The remaining portion of variable costs are comprised of miscellaneous operating and utility costs. Miscellaneous operating costs were $\$ 36,710$, $\$ 83,784$, and $\$ 104,417$ for the small, medium, and large plants operating at 100 percent of designed capacity. Total annual costs and their various com- 
ponents at $70,80,90,100$, and 120 percent of capacity utilization are presented in Tables 18 and 19.

Utility costs ranged from $\$ 2,021$ to $\$ 2,622$ for the small plant, $\$ 4,033$ to $\$ 5,611$ for the medium plant, and $\$ 5,150$ to $\$ 7,159$ for the large plant (Table 19). Utility costs, expressed as a percent of total costs, also are presented in Table 19.

\section{Average Costs}

The average costs obtained for the three model plants operating at their designed capacities (100 percent capacity utilization) were $\$ 81.47$ per head for the small plant, $\$ 56.15$ per head for the medium plant, and $\$ 55.35$ per head for the large plant (Table 20).

Assuming the plants would operate at designed capacity, the optimum scale of plant to construct would be plant $\mathrm{C}$. This plant has the lowest average costs and occupies the lowest point on the long-run average cost curve (Figure 1). However, if slaughter animal supply is limited and plants are unable to operate at full capacity, then the small plants may attain the cost advantage. For example, at full capacity the medium plant slaughters and processes (for a lower per head cost) the same number of head per year as the large plant operating at 80 percent capacity.

\section{REVENUE AND FEASIBILITY ANALYSIS \\ Revenue Analysis}

In order to completely evaluate the feasibility of establishing the model plants described in this study, it was necessary to approximate revenues that would have resulted from the operation of such plants at various levels of capacity utilization. To accomplish this, a net value per head processed was determined and then multiplied by appropriate units of output (Table 21).

\section{Revenue per unit}

According to West Virginia Department of Agriculture officials, charges for custom slaughtering and processing vary widely throughout the state. Therefore, in order to best approximate possible revenues from the opera. tion of such plants in all areas of West Virginia, three levels of revenue were used. For this analysis, they were called low, medium, and high.

Revenues per head processed for the various revenue levels were calculated as follows:

1. A base slaughtering fee of $\$ 5.00$ for the low revenue level, $\$ 10.00$ for the medium level, and $\$ 15.00$ for the high revenue level was charged.

2. A processing fee of 10,12 , and 14 cents per lb. of dressed weight was charged for the low, medium, and high revenue levels. ${ }^{2}$

3. Additional revenue per animal processed for hide and offal was estimated at $\$ 2.00$ per $100 \mathrm{lb}$. of liveweight. ${ }^{3}$

\footnotetext{
${ }^{2}$ Dressed weight per animal processed was calculated by multiplying average West Virginia liveweight for 1976 (892 Ibs.), times average U.S. dressing percentage for 1976 (59 percent). Calculated this way, the average dressed weight for 1976 was 525 lbs.

${ }^{3}$ The figure of $\$ 2.00$ per $100 \mathrm{lbs}$. of liveweight is 50 percent of the average for 1976 based on current central U.S. prices and averaged by-product yields (27, p. 1220). According to plant managers, this figure represents the additional revenue received from the sale of hide and offal.
} 


\section{FIGURE 1}

Short and Long-Run Average Cost Curves

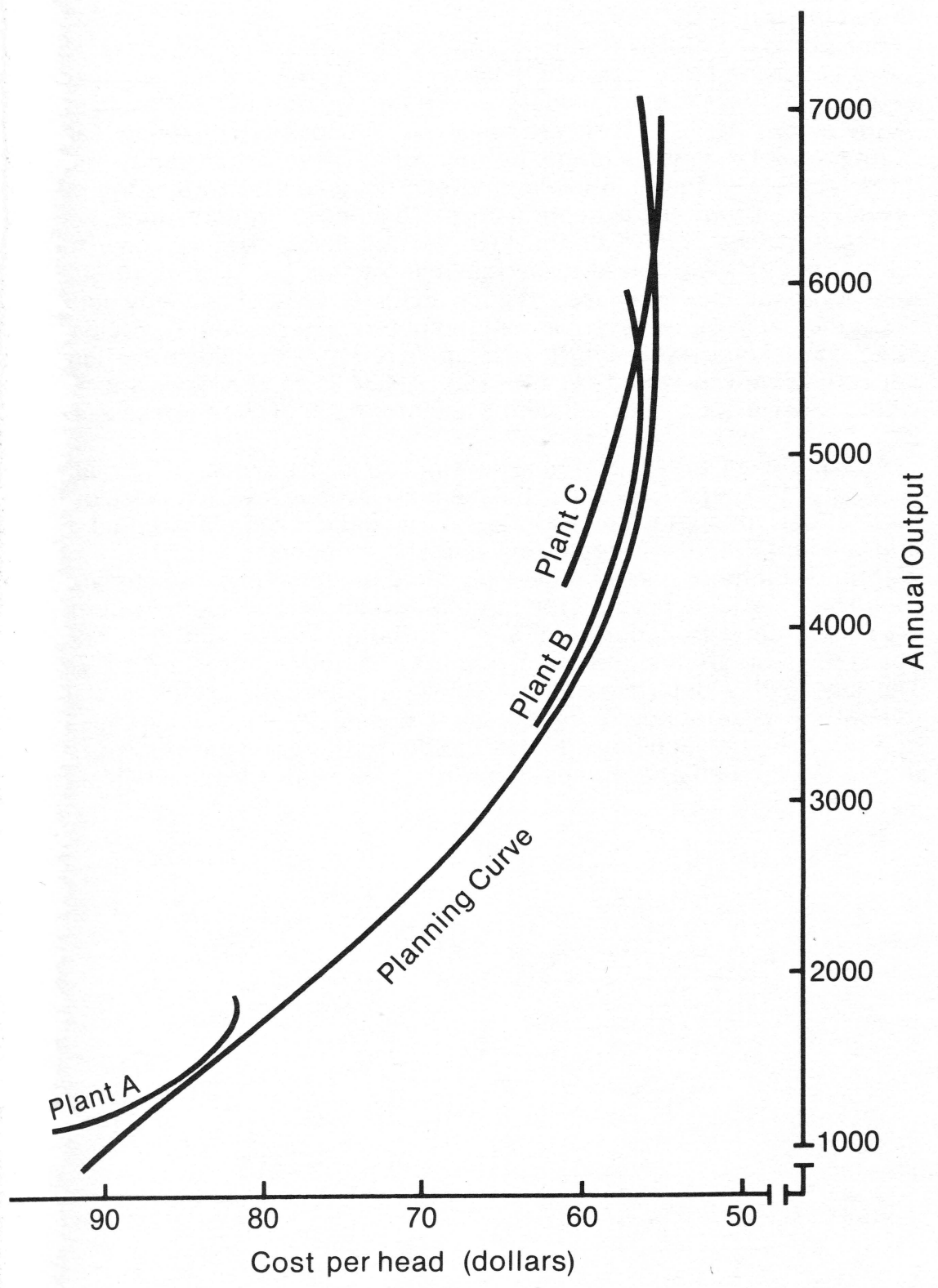


By combining revenues from the three sources above, the three levels of revenue per unit processed were obtained. They were $\$ 75.34$ for the low level, $\$ 90.84$ for the medium level, and $\$ 106.34$ for the high level. By multiplying these levels by the appropriate units of output, complete revenue schedules were obtained (Table 22).

\section{Feasibility Analysis}

For purposes of this study, a plant is considered feasible if total sales (revenue) exceed total costs or if net revenue is greater than zero. In order to estimate net revenue, total costs were subtracted from total sales for each of the model plants at their various levels of capacity utilization (Table 23).

All three of the model plants at their various levels of capacity utilization were feasible at the high revenue level. This was also true of the medium revenue level, with the exception of the 70 percent capacity utilization level of the smallest plant. For the low revenue level, however, only the two largest plants were found to be feasible. At this low level of revenue, the smallest plant incurred a loss at each assumed level of capacity utilization.

On the basis of net revenue per animal processed, Plant A would receive $\$ 24.77, \$ 9.63$, and $-\$ 6.23$ for the respective revenue levels of operating at full capacity. Plant B would receive $\$ 50.19, \$ 34.69$, and $\$ 19.19$ and Plant C would receive $\$ 50.99, \$ 35.49$, and $\$ 19.99$ for each of the three levels (Table 24).

Assuming an average dressed weight of 525 pounds, the small plant would net $1.8^{\natural}$ per pound under the medium revenue level (base fee of $\$ 10.00$ and $12^{4}$ per pound) at full capacity. The medium sized plant would net $6.4^{\circ}$ and the large Plant (C) would realize $6.8^{\circ}$ per pound.

If the slaughtering and processing costs in this study are compared with the lower costs incurred by the large Midwestern and Southwestern firms, plus the greater transportation and distribution costs from those areas, it might be more efficient for small plants to be constructed in West Virginia. The key to this determination would be the availability of live slaughter animals. A year-round steady supply is necessary for efficient, least cost operation. Since each individual situation is different, individuals or groups interested in such enterprises might find this study of some help. 
Tables $1-24$ 
Table 1

Building Costs

Item

Delivery and erection of pre-engineered building

Excavating, paving, land-

scaping, tar and gravel

roof, building holding

pens

Drain lines, plumbing and installation

Electrical lines

Total building costs ${ }^{d}$

Plant $A^{a} \quad$ Plant $B^{b} \quad$ Plant $C^{c}$

dollars

$39,972 \quad 79,420$

89,900

$8,000 \quad 35,000 \quad 35,000$

$7,000 \quad 23,000 \quad 26,000$

$6,500 \quad 20,000 \quad 22,000$

$\begin{array}{lll}61,472 & 157,420 & 172,900\end{array}$

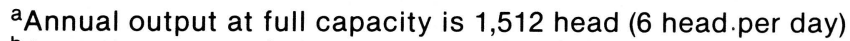

${ }^{b}$ Annual output at full capacity is 5,040 head ( 20 head per day)

cAnnual output at full capacity is 6,300 head ( 25 head per day)

dBuilding costs, especially lumber, has increased since the study was undertaken (1977) and since this report was submitted for publication (September, 1977).

\section{Table 2}

Equipment Costs

\begin{tabular}{lrrr}
\hline Item & Plant A & Plant B & Plant C \\
\hline $\begin{array}{l}\text { Slaughtering and } \\
\text { processing equipment }\end{array}$ & 16,265 & 42,127 & 42,129 \\
Refrigeration equipment & 14,927 & 32,975 & 36,900 \\
Office equipment & 1,530 & 2,255 & 2,255 \\
$\begin{array}{l}\text { Employee welfare } \\
\text { area equipment }\end{array}$ & 555 & 1,260 & 1,495 \\
$\begin{array}{l}\text { Total equipment costs, } \\
\text { delivered and installed }\end{array}$ & 33,277 & 78,617 & 82,779
\end{tabular}




\section{Table 3}

Building, Parking, and Miscellaneous

Land Area Requirements and Costs

\begin{tabular}{lrrr}
\hline Item & Plant A & Plant B & Plant C \\
\hline Building & 1,520 & square feet & \\
Employee parking & & 2,560 & 4,850 \\
Visitor parking & 1,890 & 4,320 & 5,130 \\
Future expansion & 1,890 & 4,320 & 5,130 \\
and landscaping & & & \\
Total requirements & 530 & 1,120 & 1,511 \\
\hline Total land costs & 5,830 & 12,320 & 16,621 \\
\hline
\end{tabular}

${ }^{a}$ An Area of 270 square feet per fulltime employee

bOne hundred percent of employee parking area

'Ten percent of the combined building space and employees' and visitors' parking areas

dBased on the assumptions of this study, only $\$ 669.00$ worth of land, valued at $\$ 5,000$ per acre, is required. It is doubtful whether one could purchase $\$ 669.00$ worth of industrial acreage but in order to compare model plants of different sizes, consistency had to be maintained in cost estimation procedures.

Table 4

Total Investment Costs

\begin{tabular}{lrrr}
\hline Item & Plant A & Plant B & Plant C \\
\hline Building costs & 61,472 & dollars & 157,420 \\
Equipment costs & 33,277 & 78,617 & 172,400 \\
Land costs & 669 & 1,414 & 1,908 \\
Total investment costs & 95,418 & 237,451 & 257,587
\end{tabular}




\section{Table 5}

Interest Costs on Land, Buildings, and Equipment

\begin{tabular}{lrrr}
\hline Item & Plant A & Plant B & Plant C \\
\hline Land & 62.00 & $\begin{array}{r}\text { dollars } \\
131.00\end{array}$ & 177.00 \\
Buildings & $2,849.00$ & $7,296.00$ & $8,014.00$ \\
Equipment & $1,542.00$ & $3,644.00$ & $3,837.00$ \\
Total interest costs & $4,453.00$ & $11,071.00$ & $12,028.00$
\end{tabular}

\section{Table 6}

Annual Depreciation Costs of Buildings and Equipment

\begin{tabular}{lrrr}
\hline Item & Plant A & Plant B & Plant C \\
\hline Total building costs & 61,472 & 157,420 & 172,900 \\
Building depreciation $^{\mathrm{a}}$ & 2,459 & 6,297 & 6,916 \\
Total equipment costs & 33,277 & 78,617 & 82,779 \\
Salvage $^{\text {b }}$ & 3,328 & 7,862 & 8,278 \\
Balance for depreciation $^{\mathrm{c}}$ & 29,949 & 70,755 & 74,501 \\
Equipment depreciation $^{\mathrm{d}}$ & 2,394 & 5,660 & 5,960 \\
Total depreciation costs $^{\mathrm{e}}$ & 4,853 & 11,957 & 12,876 \\
\hline
\end{tabular}

aFour percent of total building costs

${ }^{b}$ Ten percent of total equipment costs

${ }^{\mathrm{c}}$ Total equipment costs minus salvage value

${ }^{\mathrm{d}}$ Eight percent of balance for depreciation

${ }^{\mathrm{e}}$ Building depreciation plus equipment depreciation 
Table 7

Annual Investment Costs

\begin{tabular}{lccc}
\hline Item & Plant A & Plant B & Plant C \\
\hline & & dollars & \\
Interesta $^{\mathrm{a}}$ & 4,453 & 11,071 & 12,028 \\
Depreciation & & & \\
Property taxes & 4,853 & 11,957 & 12,876 \\
Insurance & 1,317 & 3,277 & 3,555 \\
$\begin{array}{l}\text { Total annual } \\
\text { investment costs }\end{array}$ & 1,244 & 2,707 & 3,597 \\
\hline
\end{tabular}

${ }^{\text {a }}$ Taken from Table 5

bTaken from Table 6 


\section{Table 8}

Electricity Requirements and Costs

\begin{tabular}{lrrr}
\hline Item & Plant A & Plant B & Plant C \\
\hline $\begin{array}{lrrr}\text { Billing demand in } \\
\text { kilowatts }^{\text {a }}\end{array}$ & 10 & 17 & 25 \\
Kilowatt hours per month & 2,192 & 4,266 & 6,269 \\
Monthly billb & $\$ 115$ & $\$ 185$ & $\$ 258$ \\
Annual cost & $\$ 1,378$ & $\$ 2,215$ & $\$ 3,091$
\end{tabular}

aFour kilowatts for every 1,000 kilowatt hours consumed

bElectricity rates taken from Monongahela Power Company General Service Rate Schedule "C," effective June 28, 1975

Rate

Primary portion: $\quad$ Kilowatt hours in an equal amount to the first 60 times the kilowatts of monthiy billing demand: $\$ .07359$ net (\$.07859 gross) per kwh

Secondary portion: Kilowatt hours in an amount equal to the product of the next 120 times the kilowatts of the monthly billing demand:

For first 840 kilowatt hours $-\$ .06339$ net per kwh

For all over 840 kilowatt hours $-\$ .02869$ net per kwh

Excess portion:

Remainder of energy used in excess of the primary and secondary portions, provided that not less than 840 kilowatt hours have been billed in the secondary portion: $\$ .01809$ net per kwh 
Table 9

Annual Electricity Costs at Various

Levels of Capacity Utilization

\begin{tabular}{llll}
\hline $\begin{array}{l}\text { Percent } \\
\text { Capacity } \\
\text { Utilization }\end{array}$ & Plant A & Plant B & Plant C \\
\hline & & dollars & \\
120 & $1,431.00$ & $2,342.00$ & $3,290.00$ \\
100 & $1,378.00$ & $2,215.00$ & $3,091.00$ \\
90 & $1,351.00$ & $2,151.00$ & $2,992.00$ \\
80 & $1,324.00$ & $2,088.00$ & $2,892.00$ \\
70 & $1,298.00$ & $2,024.00$ & $2,793.00$ \\
\hline
\end{tabular}


Table 10

Annual Fuel Requirements and Costs

\begin{tabular}{|c|c|c|c|}
\hline $\begin{array}{l}\text { Percent } \\
\text { Capacity } \\
\text { Utilization }\end{array}$ & Plant A & Plant B & Plant C \\
\hline & & gallons & \\
\hline 120 & 1,801 & 5,263 & 6,166 \\
\hline 100 & 1,501 & 4,386 & 5,138 \\
\hline 90 & 1,351 & 3,947 & 4,624 \\
\hline 80 & 1,201 & 3,509 & 4,110 \\
\hline \multirow[t]{2}{*}{70} & 1,051 & 3,070 & 3,597 \\
\hline & & dollarsa & \\
\hline 120 & 720.00 & $2,105.00$ & $2,466.00$ \\
\hline 100 & 600.00 & $1,754.00$ & $2,055.00$ \\
\hline 90 & 540.00 & $1,579.00$ & $1,850.00$ \\
\hline 80 & 480.00 & $1,404.00$ & $1,644.00$ \\
\hline 70 & 420.00 & $1,228.00$ & $1,439.00$ \\
\hline
\end{tabular}

a Based on a fuel cost of $\$ 0.40$ per gallon 
Table 11

Annual Water Requirements

and Costs

\begin{tabular}{|c|c|c|c|}
\hline $\begin{array}{l}\text { Percent } \\
\text { Capacity } \\
\text { Utilization }\end{array}$ & Plant A & Plant B & Plant C \\
\hline & & gallons & \\
\hline 120 & 491,221 & $1,637,767$ & $2,047,209$ \\
\hline 100 & 409,442 & $1,364,806$ & $1,706,007$ \\
\hline 90 & 368,552 & $1,228,325$ & $1,535,407$ \\
\hline 80 & 327,661 & $1,091,845$ & $1,364,806$ \\
\hline \multirow[t]{2}{*}{70} & 286,772 & 955,364 & $1,194,205$ \\
\hline & & dollars & \\
\hline 120 & 471.00 & $1,164.00$ & $1,403.00$ \\
\hline 100 & 407.00 & $1,013.00$ & $1,205.00$ \\
\hline 90 & 379.00 & 931.00 & $1,109.00$ \\
\hline 80 & 337.00 & 856.00 & $1,013.00$ \\
\hline 70 & 303.00 & 781.00 & 918.00 \\
\hline
\end{tabular}




\section{Table 12}

Total Annual Utilities Costs

\begin{tabular}{lrrr}
\hline $\begin{array}{l}\text { Percent } \\
\text { Capacity } \\
\text { Utilization }\end{array}$ & Plant A & Plant B & Plant C \\
\hline & & dollars & \\
120 & $2,622.00$ & $5,611.00$ & $7,159.00$ \\
100 & $2,385.00$ & $4,982.00$ & $6,351.00$ \\
90 & $2,270.00$ & $4,661.00$ & $5,951.00$ \\
80 & $2,141.00$ & $4,348.00$ & $5,549.00$ \\
70 & $2,021.00$ & $4,033.00$ & $5,150.00$ \\
\hline
\end{tabular}

Table 13

Personnel Required to Operate the Three Model Plants at Full Capacity

Department Plant A

Plant B

Plant C

Slaughtering

1

Cutting and boning

1

3

Order assembly

3

3

4

Office personnel

1

7

9

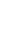

2

Sanitation and

maintenance

$.5^{a}$

1

Management

1

1

Total

7.5

17

21

aDesignates part-time employee 
Table 14

Total Wages and Benefits for Plant A

\begin{tabular}{|c|c|c|c|c|c|}
\hline Percent Capacity Utilization & 120 & 100 & 90 & 80 & 70 \\
\hline & \multicolumn{5}{|c|}{ dollars } \\
\hline In-plant labor costsa & 70,692 & 57,360 & 52,824 & 48,288 & 43,752 \\
\hline Retirement expense ${ }^{\mathrm{b}}$ & 3,605 & 2,925 & 2,694 & 2,463 & 2,231 \\
\hline Social Securityc & 4,454 & 3,614 & 3,328 & 3,042 & 2,756 \\
\hline Insurance and hospitalizationd & 4,383 & 3,556 & 3,275 & 2,994 & 2,713 \\
\hline Vacation, sick leave, holidaye & 4,948 & 4,015 & 3,698 & 3,380 & 3,063 \\
\hline All otherf & 1,131 & 918 & 845 & 773 & 700 \\
\hline Totalg & 89,213 & 72,388 & 66,664 & 60,940 & 55,215 \\
\hline
\end{tabular}

aTaken from Appendix $D$

$b_{5.1}$ percent of in-plant labor costs

${ }^{\circ} 6.3$ percent of in-plant labor costs

${ }^{d} 6.2$ percent of in-plant labor costs

e7.0 percent of in-plant labor costs

$f_{1.6}$ percent of in-plant labor costs

gSum of $a, b, c, d, e$, and $f$ 
Table 15

Total Wages and Benefits for Plant B

Percent Capacity Utilization

$$
120
$$

100

90

80

70

\begin{tabular}{|c|c|c|c|c|c|}
\hline \multirow[b]{2}{*}{ In-plant labor costs ${ }^{a}$} & \multicolumn{5}{|c|}{ dollars } \\
\hline & 165,454 & 130,912 & 119,421 & 107,929 & 96,438 \\
\hline Retirement expense ${ }^{b}$ & 8,438 & 6,677 & 6,090 & 5,504 & 4,918 \\
\hline Social Securityc & 10,424 & 8,247 & 7,524 & 6,799 & 6,076 \\
\hline Insurance and hospitalizationd & 10,258 & 8,117 & 7,404 & 6,692 & 5,979 \\
\hline Vacation, sick leave, holidaye & 11,582 & 9,164 & 8,359 & 7,555 & 6,751 \\
\hline All other & 2,647 & 2,095 & 1,911 & 1,727 & 1,543 \\
\hline Totalg & 208,803 & 165,212 & 150,709 & 136,206 & 121,705 \\
\hline
\end{tabular}

aTaken from Appendix D

${ }^{b} 5.1$ percent of in-plant labor costs

${ }^{c} 6.3$ percent of in-plant labor costs

${ }^{\mathrm{d}} 6.2$ percent of in-plant labor costs

e 7.0 percent of in-plant labor costs

${ }^{f} 1.6$ percent of in-plant labor costs

gSum of $a, b, c, d, e$, and $f$ 
Table 16

Total Wages and Benefits for Plant C

Percent Capacity Utilization

$$
120
$$

100

90

80

70

dollars

In-plant labor costs ${ }^{a}$

\begin{tabular}{rrrrr}
206,784 & 163,152 & 148,636 & 134,122 & 119,607 \\
10,546 & 8,321 & 7,580 & 6,840 & 6,100 \\
13,027 & 10,279 & 9,364 & 8,450 & 7,535 \\
12,821 & 10,115 & 9,215 & 8,316 & 7,416 \\
14,475 & 11,421 & 10,405 & 9,389 & 8,372 \\
3,309 & 2,610 & 2,378 & 2,146 & 1,914 \\
260,962 & 205,898 & 187,578 & 169,263 & 150,944 \\
\hline
\end{tabular}

aTaken from Appendix D

b5.1 percent of in-plant labor costs

${ }^{\mathrm{c}} 6.3$ percent of in-plant labor costs

${ }^{d} 6.2$ percent of in-plant labor costs

e7.0 percent of in-plant labor costs

f1.6 percent of in-plant labor costs

gSum of $a, b, c, d, e$, and $f$ 
Table 17

Annual Miscellaneous Operating Costs ${ }^{a}$

\begin{tabular}{llll}
\hline $\begin{array}{l}\text { Percent } \\
\text { Capacity } \\
\text { Utilization }\end{array}$ & Plant A & Plant B & Plant C \\
\hline & & dollars & \\
120 & 42,528 & 98,522 & 123,034 \\
100 & 36,710 & 83,784 & 104,417 \\
90 & 33,807 & 76,429 & 95,127 \\
80 & 30,904 & 69,075 & 85,838 \\
70 & 28,001 & 61,720 & 76,549 \\
\hline
\end{tabular}

aIncludes repair and maintenance, killing supply costs, office costs, processing and packaging costs, taxes and licenses, telephone, advertising, and laundry costs. 
Table 18

The Components of Total Costs (Investment, Payroll, Miscellaneous, Operating, and Utilities)

by Level of Capacity Utilization

\begin{tabular}{rrrrrrr}
\hline Plant & $\begin{array}{r}\text { Capacity } \\
\text { Utilization } \\
\text { (Percent) }\end{array}$ & Investment & Payroll & $\begin{array}{r}\text { Miscellaneous } \\
\text { Operating }\end{array}$ & Utilities & Total \\
\hline & & & dollars & & & \\
& 120 & 11,869 & 89,213 & 42,528 & 2,622 & 146,232 \\
$A^{a}$ & 100 & 11,869 & 72,388 & 36,710 & 2,385 & 123,335 \\
& 90 & 11,869 & 66,664 & 33,807 & 2,270 & 114,610 \\
& 80 & 11,869 & 60,940 & 30,904 & 2,141 & 105,854 \\
& 70 & 11,869 & 55,215 & 28,001 & 2,021 & 97,106 \\
& 120 & 29,012 & 208,803 & 98,522 & 5,611 & 341,948 \\
$B^{b}$ & 100 & 29,012 & 165,212 & 83,784 & 4,982 & 282,990 \\
& 90 & 29,012 & 150,709 & 76,429 & 4,661 & 260,811 \\
& 80 & 29,012 & 136,206 & 69,075 & 4,348 & 238,641 \\
& 70 & 29,012 & 121,705 & 61,720 & 4,033 & 216,470 \\
& 120 & 32,056 & 260,962 & 123,034 & 7,159 & 423,211 \\
$C^{c}$ & 100 & 32,056 & 205,898 & 104,417 & 6,351 & 348,722 \\
& 90 & 32,056 & 187,578 & 95,127 & 5,951 & 320,722 \\
& 80 & 32,056 & 169,263 & 85,838 & 5,549 & 292,706 \\
& 70 & 32,056 & 150,944 & 76,549 & 5,150 & 264,699 \\
\hline
\end{tabular}

aPlant $A-100 \%$ capacity $=1,512$ head per year

bPlant B $-100 \%$ capacity $=5,040$ head per year

cPlant C $-100 \%$ capacity $=6,300$ head per year 
Table 19

The Components of Total Costs (Investment, Payroll, Miscellaneous Operating, Utilities) as a Percent of

Total Costs by Level of Capacity Utilization

\begin{tabular}{|c|c|c|c|c|c|}
\hline Plant & $\begin{array}{r}\text { Capacity } \\
\text { Utilization } \\
\text { (Percent) }\end{array}$ & Investment & Payroll & $\begin{array}{r}\text { Miscellaneous } \\
\text { Operating }\end{array}$ & Utilities \\
\hline & & & percent & & \\
\hline A & $\begin{array}{r}120 \\
100 \\
90 \\
80 \\
70\end{array}$ & $\begin{array}{r}8.12 \\
9.62 \\
10.36 \\
11.21 \\
12.22\end{array}$ & $\begin{array}{l}61.01 \\
58.69 \\
58.17 \\
57.57 \\
56.86\end{array}$ & $\begin{array}{l}29.08 \\
29.76 \\
29.50 \\
29.19 \\
28.84\end{array}$ & $\begin{array}{l}1.79 \\
1.93 \\
1.98 \\
2.02 \\
2.08\end{array}$ \\
\hline B & $\begin{array}{r}120 \\
100 \\
90 \\
80 \\
70\end{array}$ & $\begin{array}{r}8.48 \\
10.25 \\
11.12 \\
12.16 \\
13.40\end{array}$ & $\begin{array}{l}61.06 \\
58.38 \\
57.78 \\
57.08 \\
56.22\end{array}$ & $\begin{array}{l}28.81 \\
29.61 \\
29.30 \\
28.95 \\
28.51\end{array}$ & $\begin{array}{l}1.64 \\
1.76 \\
1.79 \\
1.82 \\
1.86\end{array}$ \\
\hline C & $\begin{array}{r}120 \\
100 \\
90 \\
80 \\
70\end{array}$ & $\begin{array}{r}7.57 \\
9.19 \\
10.00 \\
10.95 \\
12.11\end{array}$ & $\begin{array}{l}61.66 \\
59.04 \\
58.49 \\
57.83 \\
57.02\end{array}$ & $\begin{array}{l}29.07 \\
29.94 \\
29.65 \\
29.65 \\
28.92\end{array}$ & $\begin{array}{l}1.69 \\
1.82 \\
1.86 \\
1.90 \\
1.95\end{array}$ \\
\hline
\end{tabular}


Table 20

The Components of Total Costs and Total Cost per Animal

Processed (Average Cost) by Level of Capacity Utilization

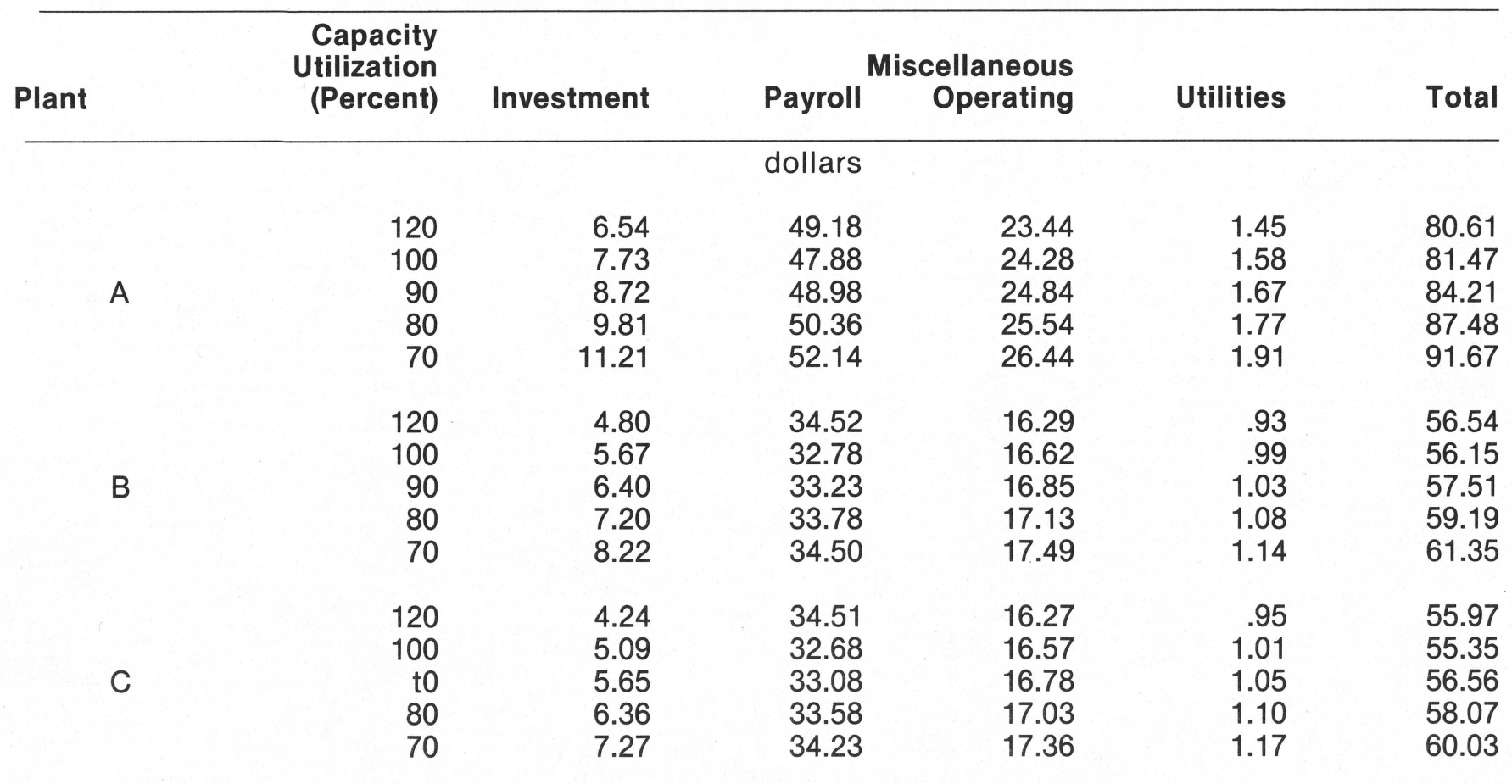


Table 21

Annual Output

\begin{tabular}{lccc}
\hline $\begin{array}{l}\text { Capacity } \\
\text { Utilization } \\
\text { (Percent) }\end{array}$ & Plant A & Plant B & Plant C \\
\hline 120 & 1,814 & head & \\
\hline 100 & 1,512 & 6,048 & 7,560 \\
\hline 90 & 1,361 & 5,040 & 6,300 \\
\hline 80 & 1,210 & 4,536 & 5,670 \\
\hline 70 & 1,059 & 3,032 & 5,040 \\
\hline
\end{tabular}


Table 22

Annual Revenue

\begin{tabular}{|c|c|c|c|c|c|c|c|c|c|}
\hline \multirow{3}{*}{$\begin{array}{l}\text { Capacity } \\
\text { Utilization } \\
\text { (Percent) }\end{array}$} & \multicolumn{9}{|c|}{ Revenue Level } \\
\hline & \multicolumn{3}{|c|}{ Plant A } & \multicolumn{3}{|c|}{ Plant B } & \multicolumn{3}{|c|}{ Plant C } \\
\hline & High & Med. & Low & High & Med. & Low & High & Med. & Low \\
\hline & \multicolumn{9}{|c|}{ dollars } \\
\hline 120 & 192,900 & 164,784 & 135,557 & 643,144 & 549,400 & 455,656 & 803,930 & 686,750 & 569,570 \\
\hline 100 & 160,786 & 137,350 & 113,914 & 535,953 & 457,834 & 379,714 & 669,942 & 572,292 & 474,642 \\
\hline 90 & 144,729 & 123,633 & 102,538 & 482,358 & 412,050 & 341,742 & 602,948 & 515,063 & 427,178 \\
\hline 80 & 128,671 & 109,916 & 91,161 & 428,763 & 366,267 & 303,771 & 535,953 & 457,834 & 379,714 \\
\hline 70 & 112,614 & 96,614 & 79,785 & 375,168 & 320,484 & 265,800 & 468,959 & 400,604 & 332,249 \\
\hline
\end{tabular}


Table 23

Net Revenue

\begin{tabular}{|c|c|c|c|c|c|c|c|c|}
\hline \multirow[t]{3}{*}{ Plant } & \multirow[t]{3}{*}{$\begin{array}{l}\text { Capacity } \\
\text { Utilization } \\
\text { (Percent) }\end{array}$} & \multicolumn{3}{|c|}{ Total Revenue } & $\begin{array}{l}\text { Total } \\
\text { Costs }\end{array}$ & \multicolumn{3}{|c|}{ Net Revenue } \\
\hline & & & enue Level & & & & evenue Le & \\
\hline & & High & Medium & Low & & High & Medium & Low \\
\hline \multirow{5}{*}{ A } & 120 & 192,900 & 164,784 & 136,667 & 146,232 & 46,668 & 18,552 & $-9,565$ \\
\hline & 100 & 160,786 & 137,350 & 113,914 & 123,335 & 37,451 & 14,015 & $-9,421$ \\
\hline & 90 & 144,729 & 123,633 & 102,538 & 114,854 & 30,119 & 9,023 & $-12,072$ \\
\hline & 80 & 128,671 & 109,916 & 91,161 & 105,854 & 22,817 & 4,062 & $-14,693$ \\
\hline & 70 & 112,614 & 96,200 & 79,785 & 97,106 & 15,508 & -906 & $-17,321$ \\
\hline \multirow{5}{*}{ B } & 120 & 643,144 & 549,400 & 455,656 & 341,948 & 301,196 & 207,452 & 113,708 \\
\hline & 100 & 535,953 & 457,834 & 379,714 & 282,990 & 252,963 & 174,844 & 96,724 \\
\hline & 90 & 482,358 & 412,050 & 341,742 & 260,811 & 221,547 & 151,239 & 80,931 \\
\hline & 80 & 428,763 & 366,267 & 303,771 & 238,641 & 190,122 & 127,626 & 65,130 \\
\hline & 70 & 375,168 & 320,484 & 265,800 & 216,470 & 158,698 & 104,014 & 49,330 \\
\hline \multirow{5}{*}{ C } & 120 & 803,930 & 686,750 & 569,570 & 423,211 & 380,719 & 263,539 & 146,359 \\
\hline & 100 & 669,942 & 572,292 & 474,642 & 348,722 & 321,220 & 223,570 & 125,920 \\
\hline & 90 & 602,948 & 515,063 & 427,178 & 320,712 & 282,236 & 194,351 & 106,466 \\
\hline & 80 & 535,953 & 457,834 & 379,714 & 292,706 & 243,247 & 165,128 & 87,008 \\
\hline & 70 & 468,959 & 400,604 & 332,249 & 264,699 & 204,260 & 135,905 & 67,550 \\
\hline
\end{tabular}




\section{Table 24}

Net Revenue Per Animal Processed

By Level of Capacity Utilization at

High, Medium and Low Revenue Levels

\begin{tabular}{|c|c|c|c|c|c|}
\hline Plant & $\begin{array}{r}\text { Capacity } \\
\text { Utilization } \\
\text { (Percent) }\end{array}$ & $\begin{array}{l}\text { Annual } \\
\text { Output } \\
\text { (Head) }\end{array}$ & High $^{\wedge}$ & $\begin{array}{l}\text { nue Per Animal } \\
\text { Medium }\end{array}$ & Low \\
\hline & & & & dollars & \\
\hline$A$ & $\begin{array}{r}120 \\
100 \\
90 \\
80 \\
70\end{array}$ & $\begin{array}{l}1,814 \\
1,512 \\
1,361 \\
1,210 \\
1,059\end{array}$ & $\begin{array}{l}25.72 \\
24.77 \\
22.13 \\
18.86 \\
14.64\end{array}$ & $\begin{array}{r}10.22 \\
9.63 \\
6.63 \\
3.36 \\
-0.85\end{array}$ & $\begin{array}{r}-5.27 \\
-6.23 \\
-8.87 \\
-12.14 \\
-16.36\end{array}$ \\
\hline$B$ & $\begin{array}{r}120 \\
100 \\
90 \\
80 \\
70\end{array}$ & $\begin{array}{l}6,048 \\
5,040 \\
4,536 \\
4,032 \\
3,528\end{array}$ & $\begin{array}{l}49.80 \\
50.19 \\
48.84 \\
47.15 \\
44.98\end{array}$ & $\begin{array}{l}34.30 \\
34.69 \\
33.34 \\
31.65 \\
29.48\end{array}$ & $\begin{array}{l}18.80 \\
19.19 \\
17.84 \\
16.15 \\
13.98\end{array}$ \\
\hline$C$ & $\begin{array}{r}120 \\
100 \\
90 \\
80 \\
70\end{array}$ & $\begin{array}{l}7,560 \\
6,300 \\
5,670 \\
5,040 \\
4,410\end{array}$ & $\begin{array}{l}50.35 \\
50.99 \\
49.78 \\
48.26 \\
46.32\end{array}$ & $\begin{array}{l}34.86 \\
35.49 \\
34.28 \\
32.76 \\
30.82\end{array}$ & $\begin{array}{l}19.36 \\
19.99 \\
18.78 \\
17.26 \\
15.32\end{array}$ \\
\hline
\end{tabular}




\section{Bibliography and Literature Cited}

(1) American Meat Institute. Financial Facts About the Meat Packing Industry, 1975.

(2) ASHRAE. Guide and Data Book Applications. American Society of Heating, Refrigeration and Air Conditioning Engineers, 1971.

(3) ASHRAE. Handbook of Air Conditioning, Heating and Ventilating. Second Edition. Industrial Press, Inc., New York.

(4) ASHRAE. Handbook of Fundamentals. The American Society of Heating, Refrigeration and Air Conditioning. Wisconsin, 1972.

(5) Bressler, R. G. Jr. "Research Determination of Economies of Scale," Journal of Farm Economics, Vol. 27, No. 3 (August, 1945).

(6) Cassell, Guy R., and D. A. West. Assembly and Slaughtering Costs for Hogs in North Carolina. North Carolina Economic Research.

(7) Economics of Scale in Cattle Slaughtering Plants. Supplement No. 2 to Technical Study No. 1. Washington: National Commission on Food Marketing, June 1966.

(8) Franzmann, John R., and B. T. Kuntz. Economies of Size in Southwestern Beef Slaughter Plants. Oklahoma Agricultural Experiment Station Research Bulletin B-648. Oklahoma State University, April 1966.

(9) Freund, John E., and Frank J. Williams. Modern Business Statistics. Englewood Cliffs, New Jersey. Prentice-Hall, Inc., 1958.

(10) Hammons, Donald R. Cattle Killing - Floor Systems and Layouts. Marketing Research Report No. 657. Washington: Agricultural Research Service, U. S. Dept. of Agriculture, May 1964.

(11) Hammons, Donald R., and Jarvis E. Miller. Improving Methods and Facilities for Cattle Slaughtering Plants in the Southwest. Marketing Research Report No. 436. Washington: Agricultural Marketing Service, U. S. Dept. of Agriculture, February 1961.

(12) Koch Supplies, Inc. Koch General Catalog, No. 194. Missouri: Koch Supplies, Inc., October 1975.

(13) Kuehn, John P. A Survey of Meat Slaughtering and Processing in West Virginia. West Virginia University Agricultural Experiment Station Bulletin 631, February 1974.

(14) Kuehn, John P. "Cost and Efficiencies of Model Meat Packing Plants in the Tennessee Valley." Unpublished Dissertation, The University of Tennessee, December 1969.

(15) Logan, J. H. and Gordon A. King. Economies of Scale in Beef Slaughter Plants. California Agricultural Experiment Station, Giannini Foundation Research Report No. 260. Berkeley: University of California, December 1967.

(16) Leftwich, Richard H. The Price System and Resource Allocatic.1. Third Edition. New York: Holt, Rinehart and Winston, 1966. 
(17) Madden, J. Patrick. Economies of Size in Farming. Economic Research Service, U. S. Dept. of Agriculture, Ag. Ec. Report No. 107. Washington: U. S. Government Printing Office, 1967.

(18) Organization and Competition in the Livestock and Meat Industry. Technical Study No. 1. Washington: National Commission on Food Marketing, June 1966.

(19) Sanders, Adolph, O. L. Frazier, and J. H. Padgett. An Appraisal of Economic Efficiencies Within Slaughter Plants. Georgia Agricultural Experiment Station Bulletin 122. Athens: University of Georgia, December 1964.

(20) Sewell, Ike J., and S. K. Winfree. "Potential Supply Estimates for a Cooperative Slaughter Plant." University of Tennessee, July 1975.

(21) Schnake, L. D. "Economics of Size in Non-Slaughtering Meat Processing Plants." Unpublished Master Thesis, University of Missouri, May 1967.

(22) U. S. Bureau of the Census, Statistical Abstract of the United States. 96th edition. Washington, 1975.

(23) United States Department of Agriculture. Federally Inspected Livestock Slaughter by Size and Type of Plant. Statistical Bulletin No. 549, Economic Research Service, Washington, May 1976.

(24) United States Department of Agriculture. Livestock and Meat Situation. Economic Research Service, LMS-209. Washington, June 1976.

(25) United States Department of Agriculture. Livestock and Meat Statistics. Supplement for 1975. Economic Research Service. Statistical Bulletin No. 522. 1976.

(26) United States Department of Agriculture. Livestock Slaughter Annual Summary 1975. Statistical Reporting Service. Washington, April 1976.

(27) United States Department of Agriculture. Market News Weekly Summary and Statistics. Livestock Division. Agricultural Marketing Service.

(28) United States Department of Agriculture. Trends in Livestock Marketing Before and After the Consent Decree of 1920 and the Packers and Stockyard Act of 1921. Packers and Stockyard Administration. June 1975.

(29) West Virginia Department of Agriculture. Annual Report. July 1, 1974 June 30, 1975. Charleston, W.Va., September 1975.

(30) West Virginia Department of Agriculture. Monthly Livestock Report. Charleston, West Virginia, February 1977. 
Blank Page in Original Bulletin 
Appendixes 


\section{APPENDIX A}

Table 1

Equipment Requirements for Plant A

\section{Item No Quantity Total

Slaughtering and Processing Equipment

1

2

3

1 Knocking pen door

1 Knocking pen door and platform

1 Hoist for door

1 Hoist with chain

1 Lander

1 Splitting saw

1 Model 50-J balancer for saw

1 Saw sterilizer

1 Electric element for saw sterilizer

1 Skinning cradle

1 Blood drum

1 Scale

1 Head rack

2 Sterilizing lavatories

2 Knife boxes

2 Drinking fountain

1 Stunner

$1 \mathrm{M}$ Cartridges for stunner

1 Band saw

1 Boning table

1 Board for table

1 Wrapping table

2 Paper cutters

1 Scale

1 Pan for scale

1 Grinder

1 Knife for grinder

$13 / 8$ " plate for grinder

$13 / 4$ " plate for grinder

2 Freezer trucks

2 Freezer racks

11 Freezer racks

200 Baskets

1 Hose

1 Nozzle

1 Barrel truck

2 Drums

2 Dollies 
2 Lugs

2 Thermometers

6 Skinning knives

6 Boning knives

2 Steels

2 Sticking knives

2 Scabbards

1 Knife sharpener

1 Breaking saw

2 Boning hooks

1 Stock prod

1 Tape machine

2 Caps

2 Aprons

1 Easy drop

Total-delivered and installed

$\$ 16,265$

Refrigeration Equipment

1 Chill cooler, 30 degrees F. CB 3H2-

LDT 1801 Bohnmizer System, 230/60/3

1 Holding cooler, 35 degrees F. CB1-1/

2M1-ADT 1040 Bohnmizer System, 230/60/3

1 Processing room, 50 degrees $F$. CB1-1/2H1-L0870 Bohnmizer System 230/60/3

1 Freezer, -15 degrees F. CB5L4FL2402 Bohnmizer System, 230/60/3

- Copper fitting, pipe insulation and gas refrigerant

Total-delivered and installed

\section{Office Equipment}

1 Typewriter

2 2-drawer file cabinet

1 4-drawer file cabinet

1 Storage cabinet

1 Desk model calculator

Total-delivered and installed 
Employee Welfare Area Equipment

66

2 Clothing locker - three opening sections

671 Clothing locker - single opening section

Total-delivered and installed

Total-delivered and installed (all equipment)

Table 2

Equipment Requirements for Plant B

Item No. Quantity

Description

Slaughtering and Processing Equipment

1 Knocking pen door with platform and hoist

2 Knocking pen entrance door

2 Fabricated I-beam

2 Hoist, 2000 lb. capacity

1 Blood and water drain

1 Skinning cradle

1 Automatic lander

1 Splitting saw, 2 H.P., (three phase)

1 Model 140-k balancer for saw

1 I-beam trolley

1 Saw sterilizer

1 Electric element for sterilizer

1 Track scale

1 Dehairer

1 Cattle stunner

100 Beef trolleys

1 Paunch truck

2 Hose

2 Nozzles

50 Trolley extensions

2 Sterilizing lavatories

2 Electric knife boxes

1 Head flushing cabinets

1 6'0" long head table 
1 8'0" wrapping table

1 Board for table

1 Table

1 Board for table

1 8'0" boning table

1 Board for table

1 Pump

12 H.P. band saw

1 Tenderizer

1 3-locker section

1 Table scale

1 Stainless steel pan for scale

1 Offal pan truck

4 Hose stations

4 Hose

4 Nozzles

6 Meat trees

3 Meat trucks

6 Meat drums

18 Lugs

2 Freezer trucks galvanized

1 Freezer racks

4 Add-on racks

100 Locker baskets

2 Cleavers

1 Thermometer

3 Steels

12 Knives

6 Heading knives

12 Boning knives

2 Scabboards

4 Scabboards

1 Knife sharpener

1 Saw

6 Bone hooks

1 Tape dispenser

1 Offal brander

12 Sponges

1 Beef stamp

$1 \mathrm{M}$ Tags

6 Caps

3 Bone aprons

12 Aprons

6 Aprons

50 Caps

4 Fly fans

1 Livestock scale

1 Sink 
73

74

75

76

77

78

79

80

81

82

83

84

85

86

87

88

89

90

91

92

93

94

95

96

97

98

99

100

101

102
1 Faucet for sink

2 Head rack

1 Paunch table with hoist

1 Grinder

2 Knives

2 3/16" plates

2 3/8" plates

2 3/4" plates

2 Drop arms

2 Hoist for drop arm

2 Wash lavatories

1100 gallon water heater

1 Rack for drying storage

1 Air curtain

2 Air curtains

3 Fly fans

1 Starting rack 18" wide

2 Racks 18" wide

6 Dollies

19 \#R4112141 Day Brite Vaporlane Light

22 \#VPA75 pendant

22 \#VPGU-2 guards

22 \#VP-GL-2PL globes

11 4" floor drains

11 Lift-out strainers

Total-delivered and installed

$\$ 42,127$

Refrigeration Equipment

1 Chill cooler, 33 degrees F. CB8-H2FL550 Bohnmizer System 220/60/3

1 Holding cooler, 35 degrees F. CB3H2-FM 280 Bohnmizer System 220/60/3

1 Cutting room 50 degrees F. CB5H2-(2)-LO 1500 Bohnmizer System $230 / 60 / 3$

1 Freezer, -10 degrees F. CB7-L5-FL 330 Bohnmizer System 230/60/3

- Copper pipe, pipe insulation controls and refrigerant

Total-delivered and installed 


\section{Office Equipment}

103

104

105

106

107

108

109

110

111

3 Desk

3 Chair

2 Typewriter

2 2-drawer file cabinet

2 4-drawer file cabinet

1 Storage cabinet

2 Desk model calculator

Total-delivered and installed

$\$ 2,255$

\section{Employee Welfare Area Equipment}

$$
\begin{aligned}
& 5 \text { Clothing locker - three } \\
& \text { opening sections } \\
& 1 \text { Clothing locker - one } \\
& \text { opening section }
\end{aligned}
$$

Total-delivered and installed

Total-delivered and installed (all equipment)

\section{Table 3}

Equipment Requirements for Plant C

\section{Item No. Quantity}

Description

Slaughtering and Processing Equipment

1 Knocking pen door with platform

1 Budget hoist for door

1 Knocking pen entrance door

-1 Fabricated I-beam

2 Hoists, 2000 Ibs. capacity

1 Blood and water drain

1 Skinning cradle

1 Automatic lander

12 H.P. splitting saw

1 Model 140-k reel balancer for saw

1 Saw sterilizer

1 Electric element for sterilizer

1 Track scale

1 Paunch truck, elevator type 
Table 3 continued

15

61
1 Cattle stunner $1 \mathrm{M}$ Cattle stunner 100 Beef trolleys

1 Washing platform

3 Sterilizing lavatories

3 Electric knife boxes

2 Drinking fountain

2 Sinks

2 Faucet for sink

1 Head flushing cabinet

1 Head table

1 Board for table

1 8'0" wrapping table

1 Landing table with board

1 8'0" boning table

1 Board for table

1 8'0" grinder table with board

6 Knives

1 Tenderizer

2 3-locker section

2 Single locker section

1 Table scale

1 Stainless steel pan for scale

1 Offal pan truck

3 Hose station \#2

3 Hose, 25' long

3 Nozzle

6 Meat trees

3 Meat trucks

6 Meat drums

3 Dollies

18 Lugs

2 Dollies

2 Freezer trucks

3 Freezer racks

26 Add-on racks

400 Locker baskets

2 Cleavers

13 Thermometers

3 Steel

12 Knives

6 Heading knives

12 Boning knives

2 Scabboards

4 Scabboards

1 Knife sharpener

1 Saw 
6 Bone hooks

1 Tape dispenser

1 Offal brander

12 Sponges

1 Beef stamp

$1 \mathrm{M}$ Tags

6 Caps

3 Bone aprons

12 Aprons

6 Aprons

50 Caps

3 Fly fans

1 Livestock scale

1 Rack

1 Rack

1 Easy drop

1 Retaining cage

2 Lavatory

4 Cooler and freezer thermometer

1 Wash nozzle for beef

120 ' hose

1 Livestock prod

1 Roller pole

16 Floor drains with strainer

1 Brake rail

1 Band saw

1 Roller conveyor

1 Grinder without pan

1 Knife

$13 / 16$ " plate

$13 / 8$ " plate

$13 / 4$ " plate

Total-delivered and installed

\section{Refrigeration Equipment}

94

95

96

1 Chill cooler, 35 degrees F. CB10H1-(2)-LET 2702 Bohnmizer System 230/60/3

1 Holding cooler, 33 degrees F. CB10H1 ADT 300 Bohnmizer System 230/60/3

1 Processing room 55 degrees F. CB3H1-L0 1890 Bohnmizer System 230/60/3 
1 Blast freezer, -15 degrees F. MB15L5-FL 5502 Bohnmizer System 230/60/3

98

1 Holding freezer, -5 degrees F. CB7L5-FL 3302 Bohnmizer System $230 / 60 / 3$

Estimate of copper fittings insulation and refrigerant

Total-delivered and installed

\section{Office Equipment}

99

100

101

102

103

104

105

Desk

Chair

Typewriter

2-drawer file cabinet

4-drawer file cabinet

Storage cabinet

Desk model calculator

Total-delivered and installed

\section{Employee Welfare Area Equipment}

106

Three opening section - clothing locker

107

One opening section - clothing locker

Total-delivered and installed

Total-all equipment delivered and installed 


\section{APPENDIX B}

\section{Calculation of Electricity Requirements}

The Lumen method was used for determining the electricity requirements for lighting purposes. This procedure utilizes two equations:

1. Number of Lumens $=\frac{\text { Footcandles of illumination } \times \text { Floor area in sq. } \mathrm{ft} \text {. }}{\text { Coefficient of utilization } \times \text { Maintenance factor }}$

2. Annual $\mathrm{Kwh}=\frac{\text { Number of lamps } \times \text { Bulb wattage } \times \text { Hours used }}{1,000 \text { watts per Kwh }}$

The first equation determines the number of lumens required for plant lighting purposes. This is then divided by the number of lumens per lamp $(2,450)$ to get the number of lamps. The footcandles of illumination used was 50. The coefficient of utilization was .52 and the maintenance factor was estimated to be $.7(21$, p. 146).

Then, to determine the annual Kwh used, the number of lamps was multiplied by the wattage (40) and the number of hours of operation per year. (Number of hours of operation varied according to capacity utilization.) The product of this is annual wattage which when divided by 1,000 gives annual kilowatt requirements.

Electricity requirements for refrigeration purposes were estimated from equations taken from Cassell and West (6, p. 16-18). These equations were:

1. B.T.U.'s required to maintain room temperature $=$ Square $\mathrm{ft}$. of wall

space $\times$ Heat transfer coefficient $\quad$ (Temperature of outer wall -

Temperature required inside room)

2. B.T.U.'s required to chill meat $=$ Pounds of meat to be chilled $x$

Specific heat of beef (Unchilled meat temperature - Temperature

required inside room)

The first equation determines the amount of electricity required to maintain the desired room temperature. The heat transfer coefficient was .32 and the outer wall temperature used was $105^{\circ} \mathrm{F}$. The desired inside room temperature and square feet of all space varied from plant to plant.

The second equation estimates the heat in B.T.U.'s that must be removed to chill the meat. The specific heat of beef was .84 and the unchilled meat temperature was $102^{\circ} \mathrm{F}(4$, p. 461). Pounds of beef to be chilled and temperature required inside the room varied from plant to plant. Total B.T.U.'s estimated were divided by B.T.U.'s per Kwh provided by refrigeration units. The refrigeration units used in this study provided 9.20 B.T.U.'s per watt of electricity. 


\section{Water Rates}

Schedule No. 2

\section{AVAILABILITY OF SERVICE}

EFFECTIVE MARCH 3, 1959

Available for general domestic, commercial, and industrial service where service is furnished through meters $3 / 4$-inch or smaller in size.

\section{RATE}

First 6,000 gals. used per quarter $\$ 0.87$ per thousand gals.

Next 24,000 gals. used per quarter .59 per thousand gals.

Next 60,000 gals. used per quarter

Next 90,000 glas. used per quarter .49 per thousand gals.

All over 180,000 gals. used per quarter .40 per thousand gals. .30 per thousand gals.

Source: Morgantown Water Commission, Morgantown, WV. 


\section{APPENDIX C \\ Calculation of Fuel Requirements}

Fuel requirements were based on short-cut procedures obtained from the Handbook on Heating, Air Conditioning and Ventilation (3, p. 2-192). This procedure involves multiplying the cubic contents of the plant by multipliers given to obtain heat loss in B.T.U.'s per hour. This is then multiplied by 24 to obtain heat loss in B.T.U.'s per day and then multiplied by the number of heating days per season to obtain total heat loss per season. Once total heat loss is calculated, this estimate is divided by B.T.U.'s per gallon of fuel to determine the number of gallons required per season. An estimate of B.T.U.'s per gallon was obtained from the American Society of Heating, Refrigeration and Air Conditioning (2, p. 234). This procedure is accurate within 5-10 percent. Information necessary to calculate heating requirements is as follows:

Cubic Contents

Plant A $-8,722$

Plant B $-25,494$

Plant C $-29,862$

$$
\begin{gathered}
\text { Heating Days Per Season } \\
120 \% \text { capacity }-193 \\
100 \% \text { capacity - 161 } \\
90 \% \text { capacity - 145 } \\
80 \% \text { capacity }-129 \\
70 \% \text { capacity }-113
\end{gathered}
$$

Multiplier

6.1

B.T.U.'s per gal. 137,000 


\section{APPENDIX D}

Table 1

Labor Costs - 120\% Capacity

\begin{tabular}{lrrr}
\hline Department & Plant A & Plant B & Plant C \\
& & dollars & \\
& & & \\
Slaughtering & 11,799 & 35,397 & 47,196 \\
Cutting and boning & 11,799 & 35,397 & 47,196 \\
Order assembly & 23,598 & 55,062 & 70,794 \\
Sanitation and & & & \\
maintenance & 3,630 & 7,866 & 7,866 \\
Office personnel & 7,866 & 15,732 & 15,732 \\
Management & 12,000 & 16,000 & 18,000 \\
Total & 70,692 & 165,454 & 206,784 \\
& & & \\
\end{tabular}

Table 2

Labor Costs - 100\% Capacity

\section{Department}

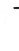

\section{Slaughtering}

Cutting and boning

Order assembly

Sanitation and

maintenance

Office personnel

Management

Total

\section{Plant A}

Plant B

Plant C

dollars

27,216

27,216

42,336

36,288

36,288

18,144

6,048

12,096

16,000

130,912
54,432

6,048

12,096

18,000

163,152 
Table 3

Labor Costs - 90\% Capacity

\begin{tabular}{lrrr}
\hline Department & Plant A & Plant B & Plant C \\
\hline & & dollars & \\
& & & \\
Slaughtering & 8,167 & 24,494 & 32,659 \\
Cutting and boning & 8,167 & 24,494 & 32,659 \\
Order assembly & 16,335 & 38,102 & 48,988 \\
Sanitation and & & & \\
maintenance & 2,722 & 5,443 & 5,443 \\
Office personnel & 5,445 & 10,886 & 10,886 \\
Management & 12,000 & 16,000 & 18,000 \\
Total & 52,824 & 119,421 & 148,636 \\
& & & \\
\hline
\end{tabular}

Table 4

Labor Costs - 80\% Capacity

\section{Department}

Slaughtering

Cutting and boning

Order assembly

Sanitation and

maintenance

Office personnel

Management

Total

\section{Plant A}

Plant B

dollars

7,258
7,258
14,515

2,419
4,838
12,000
48,288

21,773

21,773

33,869

29,030

29,030

43,546

4,838
9,677
16,000
107,929

Plant C 
Table 5

Labor Costs - 70\% Capacity

\begin{tabular}{lrrr}
\hline Department & Plant A & Plant B & Plant C \\
& & dollars & \\
& & & \\
Slaughtering & 6,350 & 19,051 & 25,402 \\
Cutting and boning & 6,350 & 19,051 & 25,402 \\
Order assembly & 12,701 & 29,635 & 38,102 \\
Sanitation and & & & \\
maintenance & 2,117 & 4,234 & 4,234 \\
Office personnel & 4,234 & 8,467 & 8,467 \\
Management & 12,000 & 16,000 & 18,000 \\
Total & 43,752 & 96,438 & 119,607 \\
& & & \\
\hline
\end{tabular}


Blank Page in Original Bulletin 
Blank Page in Original Bulletin 